\title{
sciendo
}

Current Issues in Pharmacy and Medical Sciences

Formerly ANNALES UNIVERSITATIS MARIAE CURIE-SKLODOWSKA, SECTIO DDD, PHARMACIA

\section{Hypolipidemic, hepatoprotective, nephroprotective and anti-lipid peroxidation properties of a methanol extract of Paullinia pinnata root-bark, in alloxan-induced hyperglycemic rats}

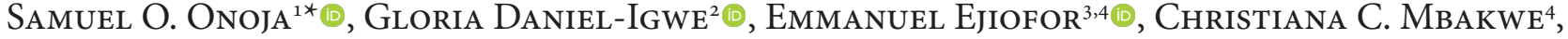 \\ Ugochuhwu S. Okeke ${ }^{4}$, Maxwell I. Ezeja ${ }^{1}{ }^{\circledR}$, Yusuf N. Omeh ${ }^{4}$, IsaAC U. Asuzu ${ }^{\circledR}$ \\ ${ }^{1}$ Department of Veterinary Physiology and Pharmacology, Michael Okpara University of Agriculture, Umudike, PMB 7267 Umuahia, Nigeria \\ 2 Department of Veterinary Pathology, Michael Okpara University of Agriculture, Umudike, PMB 7267 Umuahia, Nigeria \\ ${ }^{3}$ Department of Biological Sciences, Clifford University, Owerrinta, Abia State, Nigeria \\ ${ }^{4}$ Department of Biochemistry, Michael Okpara University of Agriculture, Umudike, PMB 7267 Umuahia, Nigeria \\ ${ }^{5}$ Department of Veterinary Physiology and Pharmacology, University of Nigeria, Nsukka, 410001 Enugu State, Nigeria
}

\begin{tabular}{|c|c|}
\hline ARTICLE INFO & ABSTRACT \\
\hline Received 02 October 2018 & \multirow[b]{3}{*}{$\begin{array}{l}\text { This study evaluated the hypolipidemic, hepatoprotective, nephroprotective and anti- } \\
\text { lipid peroxidation properties of a methanol extract of Paullinia pinnata root-bark, } \\
\text { in alloxan-induced hyperglycemic rats. The extract of } P \text {. pinnata root-bark was prepared } \\
\text { using a cold maceration method with } 80 \% \text { methanol and concentrated at } 40^{\circ} \mathrm{C} \text { in hot air } \\
\text { oven. The extract was administered once daily per os at } 50,100 \text { and } 200 \mathrm{mg} / \mathrm{kg} \text { for } 21 \\
\text { consecutive days. Distilled water }(5 \mathrm{~mL} / \mathrm{kg} \text { ) and glibenclamide }(2 \mathrm{mg} / \mathrm{kg} \text { ) were used as } \\
\text { the vehicle and reference standard, respectively. The serum lipid profile, markers of liver } \\
\text { and kidney functions, antioxidant status (malondialdehyde level, superoxide dismutase } \\
\text { and catalase activities), histopathological changes in liver and kidney were examined } \\
24 \mathrm{~h} \text { after the last treatment on day } 21 \text {. The extract reduced serum lipid profile, markers } \\
\text { of liver and kidney functions of treated rats relative to vehicle-treated rats. The superoxide } \\
\text { dismutase and catalase activities of the extract treated rats were also elevated relative } \\
\text { to the vehicle-treated rats. The extract reversed liver and kidney injuries induced by } \\
\text { alloxan in the treated rats. This study provides some basic information which suggest that } \\
P \text {. pinnata could be effective in managing diabetic complications. }\end{array}$} \\
\hline Accepted 16 January 2019 & \\
\hline $\begin{array}{l}\text { Keywords: } \\
\text { antioxidant, } \\
\text { Paullinia pinnata, } \\
\text { hepatoprotective, } \\
\text { nephroprotective, } \\
\text { lipid profile. }\end{array}$ & \\
\hline
\end{tabular}

\section{INTRODUCTION}

Diabetes mellitus is a chronic metabolic disease that affects people of all cultures, ages and social class [1]. In 2010 , the global prevalence of diabetes was 285 million and the 2030-projected prevalence is 439 million [2]. The diabetic condition is characterized by hyperglycemia and dyslipidemia. Hyperglycemia and dyslipidemia provoke elevated elaboration of reactive oxygen species such as superoxide anions, hydrogen peroxide and hydroxyl radical ions, and nonenzymatic glycation of proteins that predispose to oxidative stress [3]. Herein, oxidative stress is implicated in the development and complications of diabetes mellitus

\footnotetext{
* Corresponding author

e-mail: onoja.samuel@mouau.edu.ng; samonreal@yahoo.com
}

[4]. The main complications of diabetes are micro- and macro-vascular diseases - the major causes of hospitalization and mortality in diabetic patients $[5,6]$. The elimination of side effects or complication in the clinical management of diabetes mellitus is still a mirage in medical practice [7]. In recent times, there is increasing interest in the ethnomedical management of diabetes with natural products of plant origin. One of such plant is Paullinia pinnata - used especially in South Eastern Nigerian medicine $[8,9]$.

Paullinia pinnata L., commonly called "Bread and Cheese", belongs to the family Sapindaceae. It is described as a woody or sub-woody plant and is common in the tropical secondary forest, along stream and the savanna belt [10]. The leaf and/or root infusion or decoction is used in 
the traditional cure of erectile dysfunction, malaria, diabetes, wounds, dysentery and many bacterial infections [11]. Antityphoid, free radical scavenging, antimicrobial, fibroblast stimulatory and vascular endothelial muscle relaxant effects were reported in investigations of the crude extract and of compounds isolated from $P$. pinnata [11-13]. Flavone glycoside [14], pinnatoside [13] and Lupane triterpenoid [12], moreover, have been isolated from $P$. pinnata. In addition, Okwudili and co-researchers [9], have reported the effects of a single dose of $P$. pinnata root-bark on fasting blood glucose (FBG) of alloxan-induced diabetes. There is, however, no information on the effects of the extract on the serum biochemical and histopathological changes of alloxan-induced diabetes. Thus, we evaluated the hypolipidemic, hepatoprotective, nephroprotective and anti-lipid peroxidation properties of methanol extract of Paullinia pinnata root-bark in alloxan-induced hyperglycemic rats.

\section{MATERIALS AND METHODS}

Collection of plant material and extraction. The rootbark of Paullinia pinnata was harvested from Inyi EnuguEzike, Enugu state, Nigeria and authenticated by Mr. A.O. Ozioko. The plant material was processed, extracted using a cold maceration method with $80 \%$ methanol and concentrated in hot air oven at $40^{\circ} \mathrm{C}$ as reported by Okwudili et al. [9].

Experimental animals. Thirty male Wistar rats (100-115 g) were used for the study. The animals were housed in cages (6 per cage) in a well-ventilated room at ambient temperature $\left(25-27^{\circ} \mathrm{C}\right)$. They were served feed and tap water $\mathrm{ad}$ libitum except when fasted is recommended, as reported by Okwudili et al. [9], in line with the published guidelines of the National Research Council [15]. The experimental protocol was approved by the institutional ethic committee.

Design of the experiment. Diabetes was induced in the rats by injecting alloxan monohydrate $(160 \mathrm{mg} / \mathrm{kg})$ intraperitoneally to overnight $(16 \mathrm{~h})$ fasted rats as described by Okwudili et al. [9]. Thirty alloxan-induced hyperglycemic rats were randomly divided into 5 groups $(1-\mathrm{V} ; \mathrm{n}=6)$. The rats were treated orally once daily for 21 consecutive days as follows:

- Group I distilled water (vehicle), $5 \mathrm{ml} / \mathrm{kg}$

- Group II glibenclamide (GLB), $2 \mathrm{mg} / \mathrm{kg}$

- Group III-V received 50, 100 and $200 \mathrm{mg} / \mathrm{kg}$ of Paullinia pinnata extract (PPE), respectively.

After the treatment on day 21, the rats were fasted for 16 hours and blood was collected via the median canthus for serum sample preparation. Thereafter, they were sacrificed via cervical dislocation, followed by the excision of liver and kidney, both of which were preserved in $10 \%$ formal saline. Also, $0.50 \mathrm{~g}$ liver was collected for the preparation of $10 \%$ homogenate in phosphate buffer saline ( $\mathrm{pH} 7.0)$.

Serum Biochemical analysis. The serum after separation from the blood cells was used for estimation of total cholesterol, triglycerides, high density lipoproteins cholesterol (HDL-C), aspartate aminotransferase (AST), alanine aminotransferase (ALT), alkaline phosphatase (ALP), total protein (TP), albumin, creatinine and urea levels with the aid of a commercially available diagnostic kit (Randox Diagnostic,
United Kingdom). Serum low-density lipoprotein cholesterol (LDL-C) was calculated using Friedewald equation [16]:

$$
\begin{gathered}
\mathrm{LDL}-\mathrm{C}(\mathrm{mg} / \mathrm{dl})=\text { Total cholesterol }-(\text { Triglycerides } / 5) \\
\text { - HDL-C. }
\end{gathered}
$$

In vivo antioxidant status. The supernatant of the liver homogenate after separation with centrifuge at $1000 \mathrm{rpm}$ was used in the evaluation of lipid peroxidation, catalase and superoxide dismutase activities as described by Draper and Hadley [17], Aebi [18] and Xin et al. [19], respectively

Histopathology. The liver and kidney tissues preserved in $10 \%$ formal saline were processed and stained with haematoxylin and eosin for histopathological examination under digital light microscope ( $\times 400$ magnification $)$ as described by Donkor et al. [20].

Data analysis. The obtained data were statistically evaluated using one-way-analysis of variance (ANOVA), followed by Least Significant Difference (LSD) test with SPSS software. The mean values were considered significant at $\mathrm{p}<0.05$.

\section{RESULTS}

Effects of PPE on the lipid profile. The serum total cholesterol, triglyceride, VLDL-C and LDL-C levels were diminished $(\mathrm{p}<0.05)$ in the GLB and PPE (all doses used) treated groups relative to the vehicle-treated group. PPE (50 $\mathrm{mg} / \mathrm{kg})$ produced a elevated $(\mathrm{p}<0.05)$ serum HDL-C levels in the treated group relative to GLB- and vehicle-treated groups (Table 1)

Table 1: Effects of PPE on the lipid profile

\begin{tabular}{|l|c|c|c|c|c|}
\hline $\begin{array}{c}\text { Group } \\
(\mathrm{n}=6)\end{array}$ & $\begin{array}{c}\text { Cholesterol } \\
(\mathrm{mg} / \mathrm{dl})\end{array}$ & $\begin{array}{c}\text { Triglyceride } \\
(\mathrm{mg} / \mathrm{dl})\end{array}$ & $\begin{array}{c}\mathrm{HDL}-\mathrm{C} \\
(\mathrm{mg} / \mathrm{dl})\end{array}$ & $\begin{array}{c}\text { VLDL-C } \\
(\mathrm{mg} / \mathrm{dl})\end{array}$ & $\begin{array}{c}\text { LDL-C } \\
(\mathrm{mg} / \mathrm{dl})\end{array}$ \\
\hline Vehicle, & $94.64 \pm$ & $189.94 \pm$ & $20.28 \pm$ & $37.99 \pm$ & $36.72 \pm$ \\
$5 \mathrm{ml} / \mathrm{kg}$ & 5.19 & 23.26 & 3.18 & 4.65 & 0.72 \\
\hline $\mathrm{GLB}$, & $40.86 \pm$ & $153.12 \pm$ & $15.48 \pm$ & $30.63 \pm$ & $5.25 \pm$ \\
$2 \mathrm{mg} / \mathrm{kg}$ & $2.19^{*}$ & 16.44 & 4.41 & 3.29 & $1.07^{*}$ \\
\hline $\mathrm{PPE}$, & $59.34 \pm$ & $60.07 \pm$ & $37.93 \pm$ & $12.01 \pm$ & $10.18 \pm$ \\
$50 \mathrm{mg} / \mathrm{kg}$ & $4.16^{*}$ & $14.48^{*}$ & $2.67^{*}$ & $2.90^{*}$ & $2.67^{*}$ \\
\hline $\mathrm{PPE}$, & $59.38 \pm$ & $81.67 \pm$ & $22.52 \pm$ & $16.33 \pm$ & $20.53 \pm$ \\
$100 \mathrm{mg} / \mathrm{kg}$ & $2.41^{*}$ & $9.11^{*}$ & 2.24 & $1.82^{*}$ & $4.35^{*}$ \\
\hline $\mathrm{PPE}$, & $39.42 \pm$ & $65.33 \pm$ & $18.76 \pm$ & $13.07 \pm$ & $7.67 \pm$ \\
$200 \mathrm{mg} / \mathrm{kg}$ & $2.07^{*}$ & $18.18^{*}$ & 2.43 & $3.64^{*}$ & $2.66^{*}$ \\
\hline
\end{tabular}

Effect of PPE on liver function markers. The PPE (all doses) treatment produced no change $(p>0.05)$ in activity of ALP relative to the vehicle-treated group, while GLB treatment decreased $(p<0.05)$ the serum activity of ALP relative to the vehicle-treated group (Table 2). All doses of PPE and GLB reduced $(\mathrm{p}<0.05)$ AST and ALT activities of treated groups relative to the vehicle-treated group. Again, PPE $(50 \mathrm{mg} / \mathrm{kg})$ and GLB diminished $(\mathrm{p}<0.05)$ total protein levels of the treated group relative to the vehicle-treated group. Albumin levels of all doses of PPE- and GLB-treated groups were not significant $(p>0.05)$ when related to the vehicle-treated group (Table 2). 
Table 2. Effects of PPE on liver function markers

\begin{tabular}{|l|c|c|c|c|c|}
\hline $\begin{array}{c}\text { Group } \\
(\mathrm{n}=6)\end{array}$ & $\begin{array}{c}\text { ALP } \\
(\mathrm{IU} / \mathrm{I})\end{array}$ & $\begin{array}{c}\text { AST } \\
(\mathrm{IU} / \mathrm{I})\end{array}$ & $\begin{array}{c}\text { ALT } \\
(\mathrm{IU} / \mathrm{I})\end{array}$ & $\begin{array}{c}\text { Total } \\
\text { protein } \\
(\mathrm{g} / \mathrm{dl})\end{array}$ & $\begin{array}{c}\text { Albumin } \\
(\mathrm{g} / \mathrm{dl})\end{array}$ \\
\hline Vehicle, & $73.29 \pm$ & $145.00 \pm$ & $63.50 \pm$ & $6.54 \pm$ & $3.01 \pm$ \\
$5 \mathrm{ml} / \mathrm{kg}$ & 9.16 & 1.35 & 4.91 & 0.33 & 0.12 \\
\hline $\mathrm{GLB}$, & $37.65 \pm$ & $114.00 \pm$ & $16.00 \pm$ & $7.38 \pm$ & $3.70 \pm$ \\
$2 \mathrm{mg} / \mathrm{kg}$ & $1.10 *$ & $6.42^{*}$ & $1.79 *$ & $0.55^{*}$ & 0.26 \\
\hline $\mathrm{PPE}$, & $61.78 \pm$ & $73.00 \pm$ & $19.67 \pm$ & $5.48 \pm$ & $3.18 \pm$ \\
$50 \mathrm{mg} / \mathrm{kg}$ & 7.52 & $13.65^{*}$ & $2.38^{*}$ & $0.32^{*}$ & 0.04 \\
\hline $\mathrm{PPE}$, & $61.75 \pm$ & $92.67 \pm$ & $19.00 \pm$ & $6.37 \pm$ & $3.71 \pm$ \\
$100 \mathrm{mg} / \mathrm{kg}$ & 12.6 & $26.22^{*}$ & $1.73^{*}$ & 0.44 & 0.20 \\
\hline $\mathrm{PPE}$, & $70.53 \pm$ & $105.00 \pm$ & $27.67 \pm$ & $5.97 \pm$ & $3.18 \pm$ \\
$200 \mathrm{mg} / \mathrm{kg}$ & 11.22 & $17.61^{*}$ & $8.40^{*}$ & 0.14 & 0.12 \\
\hline
\end{tabular}

$* p<0.05$ relative to the vehicle-treated group, GLB - glibenclamide, PPE - Paullinia pinnata extract, ALP - alkaline phosphatase,

AST - aspartate aminotransferase, ALT - alanine aminotransferase

Effects of PPE on the kidney function markers. The PPE (all doses used) and GLB decreased $(\mathrm{p}<0.05)$ the serum creatinine and urea levels of treated rats relative to the vehicle-treated rats. The lowest reductions in serum creatinine and urea levels were recorded at $50 \mathrm{mg} / \mathrm{kg}$ dose of PPE (Table 3).

Table 3. Effects of PPE on the kidney function markers

\begin{tabular}{|l|l|c|}
\hline \multicolumn{1}{|c|}{ Group $(n=6)$} & Urea $(\mathrm{mg} / \mathrm{dl})$ & Creatinine $(\mathrm{mg} / \mathrm{dl})$ \\
\hline Vehicle, $5 \mathrm{ml} / \mathrm{kg}$ & $93.70 \pm 12.25$ & $0.69 \pm 0.04$ \\
\hline GLB, $2 \mathrm{mg} / \mathrm{kg}$ & $36.53 \pm 5.61^{*}$ & $0.43 \pm 0.10^{*}$ \\
\hline PPE, $50 \mathrm{mg} / \mathrm{kg}$ & $47.50 \pm 8.70^{*}$ & $0.53 \pm 0.01^{*}$ \\
\hline PPE, $100 \mathrm{mg} / \mathrm{kg}$ & $48.95 \pm 6.29 *$ & $0.62 \pm 0.06^{*}$ \\
\hline PPE, $200 \mathrm{mg} / \mathrm{kg}$ & $55.93 \pm 12.73^{*}$ & $0.64 \pm 0.01^{*}$ \\
\hline
\end{tabular}

${ }^{*} \mathrm{p}<0.05$ relative to the vehicle-treated group, GLB - glibenclamide, PPE - Paullinia pinnata extract
Effects of PPE on the antioxidant markers. All doses of PPE used and GLB diminished $(\mathrm{p}<0.05)$ the malondialdehyde levels in the treated rats when related to the vehicletreated rats $($ Table 4$)$. The PPE elevated $(\mathrm{p}<0.05)$ the activities of superoxide dismutase and catalase in the treated rats relative to the vehicle-treated rats. The antioxidant activities of PPE were comparable with the effects of GLB (Table 4).

Table 4: Effects of PPE on the antioxidant markers

\begin{tabular}{|l|c|c|c|}
\hline $\begin{array}{c}\text { Group } \\
(n=6)\end{array}$ & $\begin{array}{c}\text { Malondialdehyde } \\
(\mu \text { mole/g protein })\end{array}$ & $\begin{array}{c}\text { Catalase } \\
(\mu \text { mole/g protein })\end{array}$ & $\begin{array}{c}\text { Superoxide } \\
\text { dismutase } \\
(I U / g \text { protein })\end{array}$ \\
\hline Vehicle, $5 \mathrm{ml} / \mathrm{kg}$ & $0.13 \pm 0.00$ & $0.05 \pm 0.01$ & $2.72 \pm 0.07$ \\
\hline $\mathrm{GLB}, 2 \mathrm{mg} / \mathrm{kg}$ & $0.11 \pm 0.02 *$ & $0.33 \pm 0.00 *$ & $4.83 \pm 0.27 *$ \\
\hline $\mathrm{PPE}, 50 \mathrm{mg} / \mathrm{kg}$ & $0.02 \pm 0.00 *$ & $0.54 \pm 0.01 *$ & $5.33 \pm 0.68^{*}$ \\
\hline $\mathrm{PPE}, 100 \mathrm{mg} / \mathrm{kg}$ & $0.09 \pm 0.02 *$ & $0.10 \pm 0.24 *$ & $4.66 \pm 0.41^{*}$ \\
\hline $\mathrm{PPE}, 200 \mathrm{mg} / \mathrm{kg}$ & $0.11 \pm 0.01 *$ & $0.09 \pm 0.04 *$ & $3.88 \pm 0.92^{*}$ \\
\hline
\end{tabular}

$* \mathrm{p}<0.05$ relative to the vehicle-treated group, GLB - glibenclamide, $\mathrm{PPE}$ - Paullinia pinnata extract

The effects of PPE on the histopathological lesions induced by alloxan in the liver and kidney. The PPE (50 $\mathrm{mg} / \mathrm{kg}$ ) and GLB (showing normal hepatocyte) reversed degeneration and necrosis of hepatocytes induced by alloxan in the treated rats. The slides of PPE (100 and $200 \mathrm{mg} / \mathrm{kg}$ ) treated rats showed areas of periportal fibrosis and bile duct proliferation with area of normal hepatocyte (Fig. 1). All doses of PPE (showed normal kidney section) reversed the tubular degeneration and necrosis of kidney induced by alloxan in the treated rats (Fig. 2).
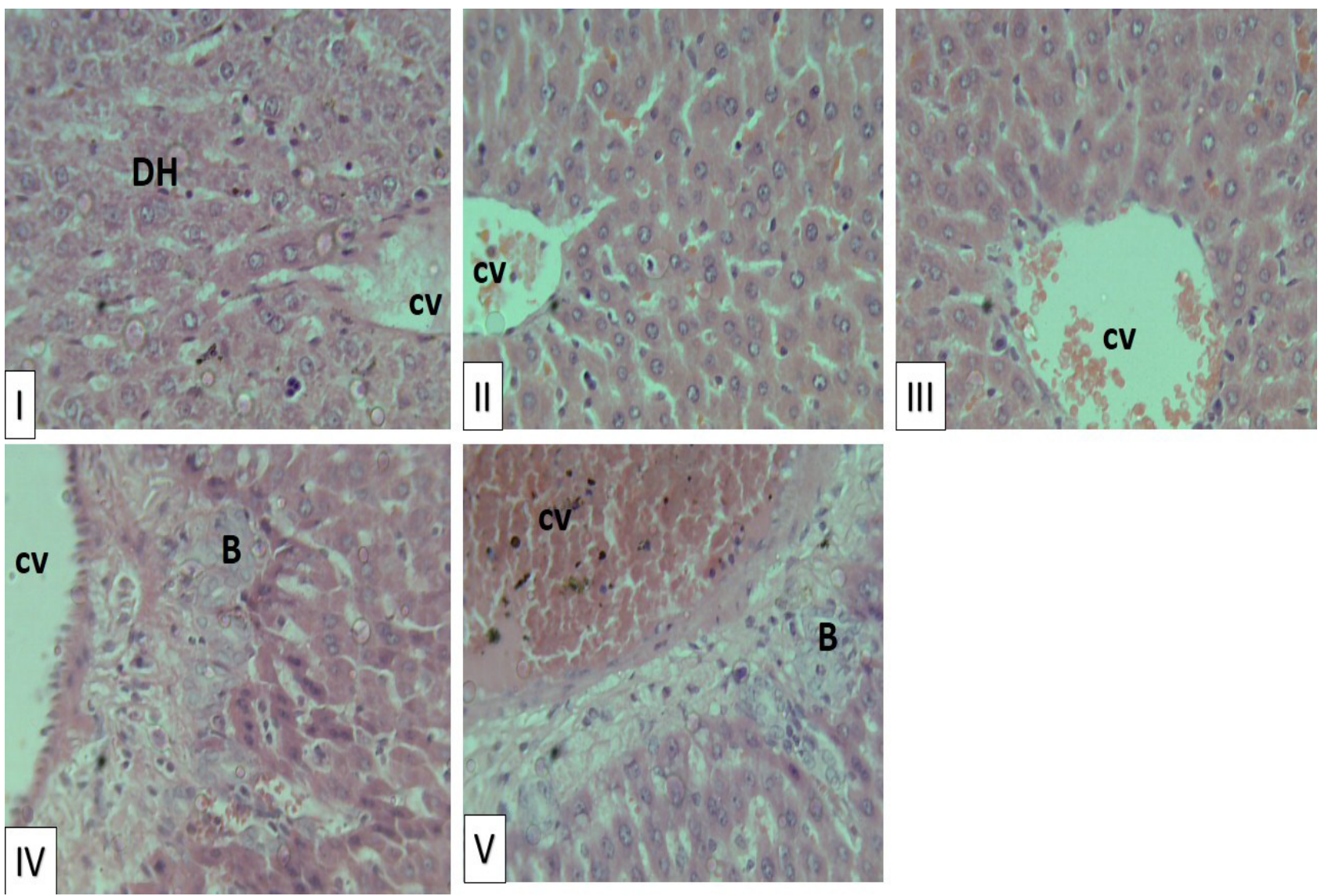

Legend: I - vehicle 5 mL/kg; II - glibenclamide 2 mg/kg; III - PPE 50 mg/kg; IV - PPE 100 mg/kg; V - PPE 200 mg/kg $\mathrm{CV}$ shows central vein; B shows bile duct, $\mathrm{DH}$ shows degenerated hepatocyte

Figure 1: Effects of PPE on liver $(\times 400 ; \mathrm{H} \& \mathrm{E})$ section of alloxan-induced hyperglycemic rats 

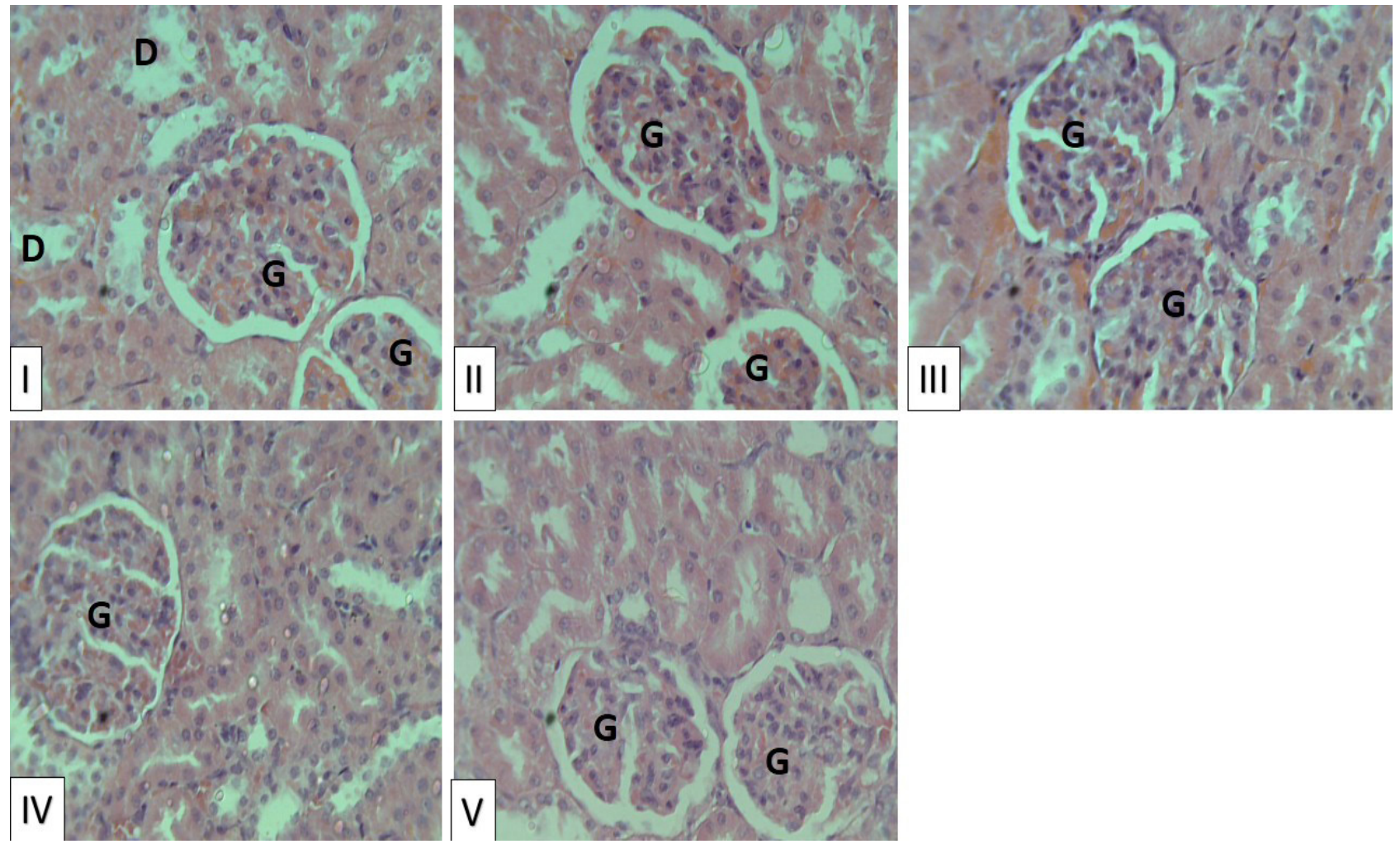

Legend: I - vehicle, $5 \mathrm{~mL} / \mathrm{kg}$; II - glibenclamide, $2 \mathrm{mg} / \mathrm{kg}$; III - PPE, $50 \mathrm{mg} / \mathrm{kg}$; IV - PPE, $100 \mathrm{mg} / \mathrm{kg} ; \mathrm{V}-\mathrm{PPE}, 200 \mathrm{mg} / \mathrm{kg}$; "G" shows the glomerulus; " $D$ " shows area of degeneration

Figure 2. Effects of PPE on kidney $(\times 400 ; \mathrm{H} \& \mathrm{E})$ section of alloxan-induced hyperglycemic rats

\section{DISCUSSION}

The study evaluated the effects of P. pinnata on the lipid profile and antioxidant status, as well as the hepatoprotective and nephroprotective potentials in alloxan-induced hyperglycemic rats. The methanol extract of $P$. pinnata exhibited hypolipidemic, antioxidant, hepatoprotective and nephroprotective activities in the treated rats. The aforementioned pharmacological activities of $P$. pinnata were mediated by the phytoconstituents [14]. The doses used here were informed by the report of a previous study [9]. The lower doses of the extract produced better effects and this could be associated with receptor site saturation and inhibition. Of note, the dose-response curve of drugs are usually sigmoid in shape due to receptor site saturation and inhibition at higher doses [21].

The extract elicited in vivo antioxidant activity that was in line with the report of Jimoh et al. [22]. This suggests that PPE has the potential to mop up free radicals and stimulate antioxidant enzyme activity [13]. This also indicates that PPE inhibited the spontaneous generation of free radicals and cell membrane damage [23].

The extract produced hypolipidemic effects and corroborated the report of Asgary et al. [24] and Sharmin et al. [25] on pomegranate juice and Momordica charantia, respectively. The mechanism of the hypolipidemic activity was not elucidated but could be linked to the stimulation of LDL-C reductase, increased bile acid production and/ or excretion, or inhibition of 3-hydroxy-3- methyl glutarylcoenzyme A reductase (HMGR) activities [26]. The hypolipidemic effect may be mediated by $\beta$-sitosterol and $\beta$-sitosterol-3-D-glucoside which have been isolated from
Paullinia pinnata [12]. The hypocholesterolemic properties of PPE suggest that it could be effective in the management of hyperlipidemia and cardiovascular diseases. Herein, every $1 \%$ reduction in serum cholesterol is associated with $2 \%$ drop in the risk of heart disease [26].

The reduced $(p<0.05)$ activities of ALP, AST and ALT, as well as diminished urea and creatinine levels in the PPE and GLB treated rats relative to distilled water treated rats suggest that PPE exhibited hepatoprotective and nephroprotective properties. The extract reversed liver and kidney damage induced by alloxan in the treated rats. The hepatoprotective activity of PPE was more at $50 \mathrm{mg} / \mathrm{kg}$ dose. The hepatoprotective and nephroprotective activities of PPE could be linked to its antioxidant property [9,22]. Antioxidants act as membrane stabilizer via the inhibition of lipid peroxidation, the product of which (malondialdehyde) induces cell membrane damage [23]. Alloxan-induced diabetes and cellular toxicity is linked to the release of free radicals. Alloxan destroys pancreatic islet and other tissues through the generation of free radicals during the redox cycling of dialuric acid - a reduction product of alloxan [27]. Past research indicates that agents that mop-up free radicals have the potential to protect against the cytotoxic effects of alloxan [27].

In conclusion, the methanol extract of $P$. pinnata exhibited hypolipidemic and antioxidant effects and also reversed hepatic and kidney damage induced by alloxan in the treated rats. Our work, hence, provides some basic information that suggests that $P$. pinnata extract (at low dose) could be used in the management of diabetic complications. 


\section{ACKNOWLEDGEMENT}

We are grateful to Mr A.O. Ozioko for the plant authentication.

\section{ANIMAL RIGHTS STATEMENT}

The Animal Ethical Committee approved the protocols.

\section{CONFLICT OF INTERESTS STATEMENT}

We declare no conflict of interests.

\section{FINANCIAL DISCLOSURE STATEMENT}

This study was not sponsored.

\section{ORCID iDs}

Samuel O. Onoja (Dhttps://orcid.org/0000-0001-6535-6110 Gloria Daniel-Igwe (D) https://orcid.org/0000-0002-5352-3564 Emmanuel Ejiofor (Dhttps://orcid.org/0000-0001-8919-0477 Maxwell I. Ezeja (Dhttps://orcid.org/0000-0002-2117-8284 Isaac U. Asuzu (Dhttps://orcid.org/0000-0001-6411-1365

\section{REFERENCE}

1. Ajiboye BO, Oloyede HOB, Salawu MO. Antihyperglycemic and antidyslipidemic activity of Musa paradisiaca - based diet in alloxan-induced diabetic rats. Food Sci Nutr. 2018;6:137-45. https:// doi.org/10.1002/fsn3.538

2. Chen L, Magliano DJ, Zimmet PZ. The worldwide epidemiology of type 2 diabetes mellitus - present and future perspectives. Nat Rev Endocrinol. 2012;8:228-36. https://doi.org/10.1038/nrendo.2011.183

3. Matsuda M, Shimomura I. Increased oxidative stress in obesity: implications for metabolic syndrome, diabetes, hypertension, dyslipidemia, atherosclerosis, and cancer. Obes Res Clin Pract. 2013;7(5):e330-e341. http://dx.doi.org/10.1016/j.orcp.2013.05.004

4. Tangvarasittichai S. Oxidative stress, insulin resistance, dyslipidemia and type 2 diabetes mellitus. World J Diabetes. 2015;6(3):456-80 https://doi.org/10.4239/wjd.v6.i3.456

5. Nweze CC, Ubhenin AE, Lay TU, Muhammad AU. Hypoglycemic, hepatoprotective and hypolipidemic effects of Pleurotus ostreatus in alloxan-induced hyperglycemic rats. Trop J Nat Prod Res. 2017;1:163-7. https://doi.org//10.26538/tjnpr/vli4.5

6. Zimmet PZ, McCarty DJ, DeCourten MP. The global epidemic of non-insulin-dependent diabetes mellitus and the metabolic syndrome. J Diabet Comp. 1997;11:60-8. https://doi.org/10.1016/ S1056-8727(96)00090-6

7. Murugan P, Pari L. Antioxidant effect of tetrahydrocurcumin in streptozotocin-nicotinamide induced diabetic rats. Life Sci. 2006;79:1720-8. https://doi.org/10.1016/j.lfs.2006.06.001

8. Kumar R, Arora V, Ram V, Bhandari A, Vyas P. Hypoglycemic and hypolipidemic effect of Allopolyherbal formulations in streptozotocin induced diabetes mellitus in rats. Int J Diabetes Mellit. 2015;3:45-50. https://doi.org/10.1016/j.ijdm.2011.01.005

9. Okwudili OS, Chimaobi NG, Ikechukwu EM, Ndukaku OY. Antidiabetic and in vitro antioxidant effects of hydromethanol extract of Paullinia pinnata root bark in alloxan-induced diabetic rat. J Complement Integr Med. 2017;15(2). https://doi.org/10.1515/jcim2015-0017

10. Adinortey MB, Sarfo JK, Adukpo GE, Dzotsi E, Kusi S, Ahmed MA, Abdul-Gafaru O. Acute and sub-acute oral toxicity assessment of hydro-alcoholic root extract of Paullinia pinnata on haematological and biochemical parameters. Biol Med. 2012;4(3):121-5. BMID: AR96-BM12
11. Lunga PK, de Dieu Tamokou J, Fodouop SP, Kuiate JR, Tchoumboue J, Gatsing D. Antityphoid and radical scavenging properties of the methanol extracts and compounds from the aerial part of Paullinia pinnata. Springerplus. 2014;3:302. https://doi.org/10.1186/2193 -1801-3-302.

12. Annan K, Houghton PJ. Two novel lupane triterpenoids from Paullinia pinnata L. with fibroblast stimulatory activity. J Pharm Pharmacol. 2010;62:663-8. https://doi.org/10.1211/jpp.62.05.0016

13. Lunga PK, Qin XJ, Yang XW, Kuiate JR, Du ZZ, Gatsing D. A new antimicrobial and radical-scavenging glycoside from Paullinia pinnata var. cameroonensis. Nat Prod Res. 2015;29:1688-94. https:// doi.org/10.1080/14786419.2014.996756

14. Abourashed EA, Toyang NJ, Choinski J, Khan IA: Two new flavone glycosides from Paullinia pinnata. J Nat Prod. 1999;62:1179-81. https://doi.org/10.1021/np990063z

15. National Research Council. Guide for the care and use of laboratory animals. National Academies Press;2010. http://www.nap.edu/ catalog/12910.html

16. Friedewald WT, Levy RI, Fredrickson DS. Estimation of the concentration of low-density lipoprotein cholesterol in plasma, without use of the preparative ultracentrifuge. Clin Chem. 1972;18: 499-502.

17. Draper HH, Hadley M. Malondialdehyde determination as index of lipid Peroxidation. Methods Enzymol. 1990;186:421-31.

18. Aebi HE. Catalase. In: Methods of enzymatic analysis. edited by HU Bergmeyer. Deerfield Beach: Verlag Chemie;1983:273-86.

19. Xin Z, Waterman DF, Hemken RW, Harmon RJ. Effects of copper status on neutrophil function, superoxide dismutase, and copper distribution in steers. J Dairy Sci. 1991;74:3078-85. https://doi. org $/ 10.3168 /$ jds.S0022-0302(91)78493-2

20. Donkor K, Okine LNK, Abotsi WKM, Woode E. Acute and subchronic toxicity studies of aqueous extract of root bark of Cassia sieberiana D.C. in rodents. J Appl Pharm Sci. 2014;4:084-9. https:// doi.org/10.7324/JAPS.2014.40415

21. Evans WC. Trease and Evans Pharmacognosy (16 ${ }^{\text {th }}$ edition). Edinburgh: WB Saunders Elsevier; 2009: 53-61.

22. Jimoh FO, Sofidiya MO, Afolayan AJ. Antioxidant properties of the methanol extracts from the leaves of Paullinia pinnata. J Med Food. 2007;10:707-11. https://doi.org/10.1089/jmf.2006.253

23. Serreli G, Incani A, Atzeri A, Angioni A, Campus M, Cauli E, et al. Antioxidant effect of natural table olives phenolic extract against oxidative stress and membrane damage in enterocyte-like cells. J Food Sci. 2017;82:380-5. https://doi.org/10.1111 /1750-3841.13613

24. Asgary S, Sahebkar A, Afshani MR, Keshvari M, Haghjooyjavanmard S, Rafieian-Kopaei M. Clinical evaluation of blood pressure lowering, endothelial function improving, hypolipidemic and antiinflammatory effects of pomegranate juice in hypertensive subjects. Phytother Res. 2014;28(2):193-9. https://doi.org/10.1002/ptr.4977

25. Sharmin ZR, Akter MT, Rahman R, Hoque M, Khan I, Mosaddek AS. Comparative study of hypolipidemic effects of Momordica Charantia (karela) with atorvastatin in fat fed rats. Journal of Human Health Research. 2017;1:11. https://doi.org/10.14302/issn.2576-9383. jhhr-17-1816

26. Ning N, He K, Wang Y, Zou Z, Wu H, Li X, Ye X. Hypolipidemic effect and mechanism of palmatine from Coptis chinensis in hamsters fed high-fat diet. Phytother Res. 2015;29:668-73. https:// doi.org/10.1002/ptr.5295

27. Szkudelski T. The mechanism of alloxan and streptozotocin action in B cells of the rat pancreas. Physiol Res. 2001;50:537-46. 